\title{
Chinese Outward Direct Investment Research: Theoretical Integration and Recommendations
}

Ping Deng

Cleveland State University, p.deng@csuohio.edu

Follow this and additional works at: https://engagedscholarship.csuohio.edu/bus_facpub

Part of the Corporate Finance Commons

How does access to this work benefit you? Let us know!

Publisher's Statement

This is the accepted version of the following article: Deng, P. (2013). Chinese Outward Direct Investment Research: Theoretical Integration and Recommendations. Management and Organization Review, 9(3), pp. 513-539. The Financial Review, Eastern Finance Association, 48, pp.597-615., which has been published in final form at 10.1111/more.12030

\section{Original Published Citation}

Deng, P. (2013). Chinese Outward Direct Investment Research: Theoretical Integration and Recommendations. Management and Organization Review, 9(3), pp. 513-539.

This Article is brought to you for free and open access by the Monte Ahuja College of Business at EngagedScholarship@CSU. It has been accepted for inclusion in Business Faculty Publications by an authorized administrator of EngagedScholarship@CSU. For more information, please contact library.es@csuohio.edu. 


\title{
Chinese Outward Direct Investment Research: Theoretical Integration and Recommendations
}

\author{
Ping Deng (邓平) \\ Cleveland State University, USA
}

ABSTRACT This article reports a detailed analysis of 138 peer-reviewed articles in 41 journals published in the last 12 years (2001-2012) that focus on Chinese outward foreign direct investment from a theoretical advancement perspective. It assesses how the topic has been explored both conceptually and empirically and identifies the substantive contributions to the literature using a thematic analysis. The article argues that research on the international expansion of Chinese multinational corporations offers a unique opportunity to extend and develop extant theorizing in four primary research streams: the latecomer perspective; Chinese state and government influences; the dynamics of firms and institutions; and the liability of foreignness. Building on the results of this analysis, the article offers five recommendations as promising ways to open up theoretical inquiry: (1) cross-fertilization among the four research streams; (2) integration of resource- and institution-based theories with other theoretical lenses; (3) research on the process dimensions using a longitudinal approach; (4) adoption of multi-levels of analysis; and (5) consideration of the wider emerging market literature.

kEYworns Chinese multinational corporations (MNCs), cross-border mergers and acquisitions (M\&As), international expansion, outward foreign direct investment (OFDI), theoretical advancement 


\section{INTRODUCTION}

China's internationalization, one of the most profound business phenomena of the last decade (Economist, 2010), is occurring in different forms. In particular, its outward foreign direct investment (OFDI) has grown exponentially to the point where China is now one of the world's largest investors with a cumulated FDI stock of over $\$ 500$ billion by 2012 (MOC, 2012; UNCTAD, 2013). As China moves to the centre of the global economy, research on the internationalization of Chinese multinational corporations (MNGs) has gained importance because China offers 'a particularly good test case for the general theory of FDI' (Buckley, Clegg, Cross, Liu, Voss, \& Zheng, 2007: 500). Despite rapidly developing research on the topic, the literature on the internationalization of Chinese firms has been fragmented and lacks theoretical integration.

Using content analysis, Deng (2012) reviewed conceptual and empirical articles from 1991 to 2010, focusing on the antecedents, processes, and outcomes of the internationalization of Chinese firms, offering insights into several content areas critically needing further development. That study, however, did not explore the theoretical implications of the internationalization of Chinese firms, specifically OFDI. Chinese internationalization presents unique features, and provides opportunities to extend existing theories and potentially develop new theories on the internationalization of firms and FDI (Child \& Rodrigues, 2005). This article systematically analyzes the literature published in the last 12 years (2001-2012) from a theoretical advancement perspective and suggests how the study of Chinese OFDI could become a major driver of theoretical development, advancing the scholarship on the internationalization of Chinese firms.

Four primary research themes assembled by scholars are adopted (see, e.g., Buckley et al., 2007; Child \& Rodrigues, 2005; Ramamurti \& Singh, 2009): (a) the latecomer perspective; (b) Chinese state and government influences; (c) the dynamics of firms and institutions; and (d) the liability of foreignness. Representative rather than exhaustive works are used to illustrate how concepts and theoretical lenses are applied and/or extended to each theme. The review is approached from an integrative, process-focused, dynamic perspective nested within cross-disciplinary knowledge and multilevel analysis, integrating previous research and offering directions for future research. The core research question asked is this: how have researchers explored Chinese internationalization through OFDI in terms of theoretical extension and development?

\section{MAPPING THE STATUS OF CHINESE INTERNATIONALIZATION RESEARCH}

\section{Method of Article Selection}

The article focuses on English-language peer-reviewed articles and excludes books, edited volumes, introductions, editorials, and other non-refereed publications. This 
is because, in recent years, journal articles have had the most impact in the ficld (Bruton \& Lau, 2008; Tsui, Nifadkar, \& Ou, 2007). In addition, articles had to address issues of Chinese internationalization at different levels of analysis. Thus, all online publications as of July 2012 were also included. Finally, the review focuses on Chinese outward direct investment, primarily through cross-border mergers and acquisitions (M\&As) and greenfield investment.

A literature search was conducted using keywords via three major electronic databases (ABI/INFORM, Academic Search Elite, and Business Source Complete); this was supplemented by a manual perusal of all issues of the relevant journals. The keywords included China, Chinese firms/companies/MNCS, international expansion, globalization/internationalization, and cross-border mergers and acquisitions (MEAs), in journal titles, abstracts, and keywords. The relevant articles were then read carefully to ensure that they were in SSCI-indexed journals and other quality journals with rigorous peer review processes. Finally, 138 articles appearing mainly in SSCI-indexed journals across various research disciplines that fit our definition of research on Chinese outward investment were identified.

The target articles were classified into three categories (left portion of Table 1). First, 39 articles appeared in nine top business and management journals; the 2010 impact factor of 1.50 was used as the cut-off point. Second, 55 articles appeared in other business and management journals; their 2010 impact factors were lower than 1.50. Finally, there were 44 articles in other international and area study journals. Table 1 shows that the number of publications increased sharply in recent years; $87 \%$ of the publications (i.e., 120 articles) were published in the last six years, indicating increasing interest in this topic. Appendix I lists the articles by author name in each category of journal.

The 138 articles were also organiszed according to their research methods (right portion of Table 1). The 78 empirical articles include 57 quantitative studies; 24 use survey or questionnaire data mainly at the firm level; 33 use archival (primarily cross-sectional) datasets at a country or industry level, using official Chinese government aggregate data, Thomson Financial SDC database, or the cross-border M\&As by listed firms in the Shanghai and Shenzhen Stock Exchanges. For the 21 qualitative empirical works, most use multiple cases or in-depth case studies and concentrate on prominent Chinese companies such as Haier, Lenovo, TCL, and Huawei. Most of the 60 conceptual or perspective papers appear in cross-cultural and international journals. They tend to focus on the macroeconomic analysis of Chinese OFDI trends and patterns and particularly in host countries such as the U.S. and African countries.

\section{Chinese OFDI and the Latecomer Perspective}

Studies have examined why Chinese firms use catch-up strategies, particularly resource-based theory (RBT), which offers an externally focused perspective of 
Table 1. Journal articles and research methodology on Chinese OFDI, 2001-2012

\begin{tabular}{|c|c|c|c|c|c|c|c|}
\hline Year & $\begin{array}{c}\text { Top business } \& \\
\text { manayement joumals }\end{array}$ & $\begin{array}{l}\text { Other business } \mathbb{E} \\
\text { management joumals }\end{array}$ & $\begin{array}{l}\text { International } \mathbb{E} \text { area } \\
\text { study joutrals }\end{array}$ & Sitbital & $\begin{array}{l}\text { Quantitative studies } \\
\text { (sumery or archival data) }\end{array}$ & $\begin{array}{c}\text { Qualitative studies } \\
\text { (single or multiple cases) }\end{array}$ & $\begin{array}{l}\text { Conceptual or } \\
\text { overview studites }\end{array}$ \\
\hline 2001 & & & 2 & 2 & & & 2 \\
\hline 2002 & & 2 & 2 & 4 & & 1 & 3 \\
\hline 2003 & 1 & 1 & l & 3 & & 1 & 2 \\
\hline 2004 & & 2 & 2 & 4 & & 1 & 3 \\
\hline 2005 & 1 & 1 & & 2 & 1 & & 1 \\
\hline 2006 & & & 3 & 3 & & & 3 \\
\hline 2007 & 6 & 3 & 3 & 12 & 3 & 2 & $\bar{j}$ \\
\hline 2008 & 5 & 3 & 3 & 11 & 4 & l & 6 \\
\hline 2009 & 5 & 8 & 11 & 24 & 10 & 4 & 10 \\
\hline 2010 & 4 & 14 & 2 & 20 & 10 & 3 & 7 \\
\hline 2011 & 5 & 7 & 14 & 26 & 11 & 4 & 11 \\
\hline $2012^{t}$ & 12 & 13 & 2 & 27 & 16 & 4 & 7 \\
\hline Total & 39 & 55 & 44 & 138 & $\begin{array}{l}57 \text { (2. survey dita; } \\
33 \text { archival data) }\end{array}$ & $\begin{array}{l}21 \text { (6 single cases; } \\
15 \text { multiple cases) }\end{array}$ & 60 \\
\hline
\end{tabular}

${ }^{\dagger}$ As of July 2012, including all the online publications. 
how Chinese firms address their competitive disadvantages and the strategies they employ to do so (Deng, 2007; Hong \& Sun, 2006). Chinese MNCs aim to overcome 'latecomer disadvantages' via aggressive acquisition of 'critical assets from mature MNEs to compensate for their competitive weakness' (Luo \& Tung, 2007: 481). To compensate for their competitive weaknesses, Chinese MNCs have set up $R \& D$ centres in high-income countries to assist in developing technologically advanced, knowledge-intensive products manufactured in China (Bonaglia, Goldstein, \& Mathews, 2007; Di Minin, Zhang, \& Gammeltoft, 2012). They have also exploited home country-specific advantages (CSAs) to build knowledge-based firm-specific advantages (FSAs) by seeking brands, distribution networks, technology, management, and strategy skills missing in Chinese firms (Rugman \& Li, 2007). Such strategic asset-seeking FDI is orchestrated mostly through large statecontrolled business groups and is well informed by in-depth case studies of some high-profile Chinese lirms, including Haier, Lenovo, Huawei, Galanz, BOE, and TCL (see, e.g., Duysters, Jacob, Lemmens, \& Yu, 2009; Ge \& Ding, 2008; Li \& Kozhikode, 201 I; Sun, 2009).

Empirical research largely supports rationales predicting the likelihood of Chinese overseas M\&As and asset-seeking motivations. Chinese MNCs undertake cross-border M\&A activities directly to seek needed ownership advantages (Huang \& Wang, 2011; Zou \& Ghauri, 2010), and reposition themselves strategically to close competitive gaps through organizational learning and/or capability building (Cardoza \& Fornes, 2011; Williamson \& Raman, 2011). In the same vein, Chinese firms are able to catch up and compress the 'time space' that would have elapsed without organizational and technological transfers (Warner, $\mathrm{Ng}, \& \mathrm{Xu}, 2004$ ). In terms of entry mode choices, Chinese firms emphasize strategic intent more strongly than strategic fit, thus accelerating international activities via overseas acquisition (Cui \& Jiang, 2009a, 2010).

However, other research has tempered support for RBT predictions of catch-up strategies by showing that asset acquisitions are not the sole determinants of Chinese overseas M\&As. Other important considerations include the firm's historical context (Buckley, Cross, Tan, Liu, \& Voss, 2008), home market exploitation (Huang \& Wang, 201 1), industry environment (Taylor, 2002), prevailing institutional norms (Yuan \& Pangarkar, 2010), corporate diversification (Cheung \& Qian, 2009), entrepreneurial orientation ( $\mathrm{Liu}, \mathrm{Li}$, \& Xue, $201 \mathrm{l}$ ), and absorptive capacities (Deng, 2010). For example, most publications in this area study and international journals argue that Chinese OFDI reflects the dynamics of investment strategies, actively responding to globalization's challenges and opportunities (see, e.g., Ning, 2009; Wong \& Chan, 2003). Moreover, OFDI expansion appears closely linked to China's expansion as a trading nation (Frost, 2004; Liu, Buck, \& Shu, 2005). Consequently, scholars argue that future studies may specify and test a comprehensive empirical model that considers all possible structural and cyclical factors in explaining the variance in Chinese OFDI flows (see, e.g., Tolentino, 2010). In 
addition, RBT predictive power may depend on the comparative resource endowments of Chinese investors at home and their adaptive capabilities in host country environments, so that some researchers empirically examine the boundaries, allowing RBT to predict catch-up strategies (Liang, Lu, \& Wang, 2012; Lu, Zhou, Bruton, \& Li, 2010). Finally, international acquisition may have become more prevalent for Chinese firms to strengthen their domestic competitive bases (Luo \& Wang, 2012; Williamson \& Raman, 2011). To the .extent that Chinese firms acquire to catch up with well-established competitors, they have the incentive to preserve the target to learn from it. Yet, research is minimal applying the relevant theories of organizational learning for knowledge transfer and capability enhancement, which creates opportunities to further refine the latecomer perspective.

In short, the latecomer logic claiming that Chinese firms internationalize to address their competitive weaknesses has become so accepted that it is less rigorously explored and tested than it could be. Thus, a large gap remains in understanding Chinese strategies in seeking assets and the implications for theoretical extensions. After all, the latecomer perspective has failed to fully predict or explain Chinese MNC international activities.

\section{Ghinese OFDI and the Role of Government and State}

Multinationals from emerging economies are constrained by institutional contexts of state interference, piecemeal economic reform, and gradual institutional evolution (Tsui, Schoonhoven, Meyer, Lau, \& Milkovich, 2004). The process of internationalization of Chinese firms 'strongly suggests that international business theory needs to take fuller account of the potential relevance of domestic institutional factors' (Child \& Rodrigues, 2005: 404). However, government's institutional role does not differentiate clearly the relation of entrepreneurs and institutions, nor does it account for recent theoretical and empirical works. This article reconfigures the role of government more broadly to include state ownership and influence as the second stream of research to better account for the publications in area study and international journals focusing on the global relevance of outward investment, particularly by Chinese state-owned enterprises (SOEs).

Articles published in the past 12 years have regarded government support as a main driver of Chinese OFDI. Using the political economy perspective, scholars examine why and how Chinese government stimulates OFDI (Deng, 2004; Luo, Xue, \& Han, 2010). They argue that OFDI promotion policies are economically imperative and institutionally complementary to offsetting the competitive weakness of Chinese MNGs in global competition. Chinese acquiring firms differed in ownership but all benefited significantly from government support at critical stages in their international efforts and their asset acquisition (Wang, 2002; Warner

et al., 2004). China's huge foreign exchange reserves, which by the end of $2012 \mathrm{had}$ 
surged to $\$ 3.5$ trillion, also facilitate government support, leading to rising statecontrolled investments (Cheung \& Qian, 2009). The state influence is cvident in that the majority of China's OFDI is conducted by SOEs, accounting for approximately $80 \%$ of Chinese cumulative investment stock (UNCTAD, 2013). State dominance means that a mix of political and commercial interests governs Chinese investment decisions, thus fuelling concern about national security risks for host countries.

The dramatic rise in Chinese FDI has sparked intense political, economic, and developmental debates in the global community regarding active state involvement envisioned by the thesis of state corporatism (Sauvant, McAllisteer, \& Maschek, 2010; Yeung \& Liu, 2008). Some scholars argue that the sharp growth of Chinese investment is the outcome of the Chinese state's 'going-out' strategy to serve its national development priorities (Song, Yang, \& Zhang, 2011). Empirical studies show that the Chinese government tends to use its investments as the main channels of commercial and political interactions to build diplomatic bridges across countries and secure goodwill for other projects that might be in China's national interests (Brautigam \& Tang, 2011; Jiang, 2009). By analyzing crossborder FDI in the Great Mekong subregion, Su (2012) explores how the Chinese state rescales to implement the go-out strategy and provides a good example of the political-economic restructuring of national states in producing new spaces of development for its landlocked Yunnan Province. Most researchers argue that investment by Chinese firms with support and subsidies from their 'developmental state' provides a promising new approach to sustainable industrialization, particularly in Nrica (see, e.g., Biggeri \& Sanfilippo, 2009; Brautigam, 2009). (On the other hand, some scholars contend that the economic and political context surrounding Chinese FDI undermines the effectiveness of environmental and social regulation in the host countries (see, e.g., Haglund, 2008; Sautman \& Yan, 2008).

China's OFDI is a complex phenomenon incorporating numerous economic and political dimensions, thereby generating location patterns that are not necessarily for profit maximization (Kang \& Jiang, 2012; Liou, 2009; Ramasamy, Yeung, \& Laforet, 2012). Chinese SOEs are often attracted to countries with great natural resources (Duanmu, 2012; Kolstad \& Wiig, 2012). Compared with peers who lack controlling state equity, Chinese SOEs are less concerned about the political risk of the host country and are more responsive to favourable exchange rates (Voss, Buckley, \& Cross, 2010). As SOEs appear to pursue complex and costly investment initiatives and frequently make risky acquisitions, theories are limited in explaining Chinese OFDI with strong state ownership and involvement (Alon, Chang, Fetscherin, Lattemann, \& McIntyre, 2009; Quer, Claver, \& Rienda, 2012).

In considering the government's role in Chinese internationalization, institutional theory dominates. The role of the Chinese government in promoting and enabling OFDI essentially reflects institutional entrepreneurship. To cxpand current theorizing, institutional studies could incorporate the political-economic 
approach. For a multi-theoretic view of Chinese government and state, researchers need to incorporate resource dependence theory (RDT) to understand the role of government (Hillman, Withers, \& Collins, 2009). State ownership creates the political affiliation of Chinese MNGs with their home country government, which increases firms' resource dependence on home country institutions, while influencing their images as perceived by host country institutional constituents. Such resource dependence and political perception could fundamentally shape the investment patterns and motives of Chinese SOEs. Because the prevailing theories focus on privately owned organizations, a fruitful research stream might be to consider how and to what extent Chinese state ownership might advance theories of FDI and firm conduct in the global landscape.

\section{Chinese OFDI and the Dynamics of Firms and Institutions}

Scholars also examine interactions between firms and institutions in shaping the behaviour, organization, and strategies of Chinese investing firms. At this micro firm-level analysis, management scholars advance both institutional and resourcebased arguments with respect to strategic options (see, e.g., Luo \& Rui, 2009). From this perspective, although the same strategic factors that apply to Western companies may explain the motivation for OFDI by Chinese MNGs, their strategic choices regarding the pattern of internationalization will be institutionally embedded (Child \& Rodrigues, 2005).

In examining the clynamic interaction between firms and institutions driving Chinese OFDI, scholars have adopted the 'strategy tripod' framework, which considers the strategic choices of Chinese MNCs as the outcome of the interplay between institutions and organizations (Peng, 2012; Yamakawa, Peng, \& Deeds, 2008). A number of studies empirically support the strategy tripod perspective (see, e.g., Lu, Liu, \& Wang, 201 l; Yang, Jiang, Kang, \& Ke, 2009a). A major advantage of the strategic tripod is that researchers may consider different analysis levels firm, industry, and country - and distinguish among different sources. However, different measurements of dependent, independent, and control variables generate conflicting empirical findings. Additionally, scholars adopting the strategic tripod lens tend to overemphasize the institutional elements, so the complex interplay between dimensions of strategic choices has been rarely tested rigorously. Without a balanced consideration of the three components, the explanatory power of the strategy tripod perspective could be another version of institutional theory.

Responding to domestic market failure in various forms, several scholars have investigated Chinese MNCs for strategic options at the micro firm-level, based on resource, institution, and transaction cost considerations. For example, formal institutional constraints, such as weak intellectual property rights (IPR) and inefficient legal frameworks discourage Chinese firms from pursuing R\&D and innovation in China. Unable to domestically develop technology, they use OFDI as an 
alternative to acquire strategic resources not easily developed in China (Deng, 2009). From this aspect, Chinese OFDI may be from perceived misalignment between firms' needs and the home country institutional and market conditions (Luo et al., 2010). In addition, fragmentation of the Chinese economy at provincial and city levels has imposed substantial costs on domestic firms so that they prefer investing overseas if it is more expensive to do business across local boundaries than to go abroad (Boisot \& Meyer, 2008). Similarly, international expansion may signify that more Chinese MNCs are determined to escape domestic limitations and competitive disadvantages incurred by operating exclusively at home (Gao, Liu, \& Zou, 2013; Liu, Wen, \& Huang, 2008). Furthermore, several researchers found that large, well-connected Chinese firms benefit most from institutional advantages (see, e.g., Voss et al., 2010), but smaller firms appear to rely more heavily on overseas networks because of institutional constraints (Lin, 2010; Zhou, 2007).

Although research has added considerable understanding of how Chinese investors actively respond to different institutional constraints, research is lacking on corporate political activities for Chinese firms, and understanding businesspolitical linkages is limited: how do Chinese firms shape or reshape government policies toward OFDI, and how do they subsequently respond or react to them once the policies are formulated? Additionally, knowing the concurrent process of policymaking is important because it helps firms identify the political, institutional, or process areas they can influence. Currently, work has failed to examine the reciprocal nature of interdependency that may jointly influence Chinese OFDI and ongoing corporate political activities. Therefore, scholars may use a co-evolutionary perspective (Lewin \& Volberda, 1999) as an effective framework for analyzing Chinese cross-border acquisitions as it allows for entrepreneurial initiative in the negotiation of evolving policies that change both contexts and firms. As the specificities of Chinese environments may generate institutionally distinct MNCs that follow different evolutionary trajectories from developed MNCs, scholars may find it productive to conceptualize the co-evolution lens as multilateral and socially constructed (Child, Rodrigues, \& Tse, 2012; Krug \& Hendrischke, 2008), thereby enabling a better understanding of how this co-evolution affects the growth and expansion of Chinese MNCs.

In sum, as with other research streams, this paper augments one theory with other theoretical approaches to explain the dynamic nature of Chinese firms and institutions. Moreover, the strategic tripod lens is a multilevel analysis considering three analysis levels; however, the critical micro-level variables - individuals and groups - have been ignored. To look more closely at the interactions of institutional and strategic choices of Chinese firms at truly multiple levels, we must incorporate micro-level managerial intentionality and organization decisionmaking processes, logically extending general FDI theory to a specific context (Buckley et al., 2007). 


\section{Chinese OFDI and the Liability of Foreignness}

A key insight of international business (IB) research is that MNCs face a substantial liability of foreignness (Zaheer, 1995). As Chinese OFDI requires strategic and structural adaptation to an expanding geographical horizon and rapid-paced technological and corporate governance change, Chinese MNCs managing their foreign operations face a heavy liability of foreignness (Globerman \& Shapiro, 2009) because they.come from a distinctive institutional and social environment. Perhaps a most salient feature is that Chinese firms are shaped by an institutional environment characterized by centralized state-controlled, authoritarian culture, and relation-based management (Tsui et al., 2004). They also have learned to cope with a complex institutional setting in which market and state interpenetrate and the corporate world and government are interlinked (Sauvant et al., 2010). Yet these distinct Chinese management styles and political connections could handicap managers of overseas affiliates.

Further, Sinophobia could undermine Chinese overseas efforts. Those sentiments have become common in business practice (Economist, 2008) in reaction to the dominant state nature of Chinese OFDI and China's relatively underdeveloped corporate social responsibilities (Peng, 2012). Therefore, researchers should explore whether (hinese firms are handicapped when entering a forcign country where government and social connection supports are not available or may become disadvantages. To overcome the liability of foreignness, both transaction cost economies (TCE) and Dunning's OLI paradigm stress that MNGs should equip their overseas subsidiaries with certain firm-specific advantages (FS $\Lambda$ ) sulficient to compensate for the nontrivial costs. Researchers realize that Chinese MNCs possess some unique advantages that allow them to operate certain types of overseas activities effectively (see, e.g., Sun, Peng, Ren, \& Yan, 2012), but most scholars highlight that Chinese firms, including national champions, lag behind in their development of FSAs, especially in innovation and managerial capabilities, so that it is hard to compete in higher value-adding markets (see, e.g., Nolan \& Zhang, 2002, 2003). This research stream presents new questions regarding how Chinese firms endeavour to overcome their institutionally and socially derived liabilities of foreignness.

Researchers have studied how Chinese MNCs, particularly small to medium enterprises (SMEs), use network-based social capital for overcoming the liability of foreignness (see, e.g., Xie \& Amine, 2010). Guanxi-related social and business networks play an important role in early internationalizing SMEs by providing unique opportunities and value in terms of information and knowledge ( $\mathrm{Zhou}, \mathrm{Wu}$, \& Luo, 2007). Other empirical findings highlight the importance of home country network ties in allowing Chinese firms to pursue new ventures internationally by mitigating information asymmetry (Yiu, Lau, \& Bruton, 2007). Such relational assets provide distinct advantages for operating in uncertain environments. By analyzing Chinese M\&As of German firms, ownership was shown to give the 
acquiring Chinese firms more discretion in how they tap into needed skills and capabilities and overcome negative German perceptions about the quality of Chinese-generated products (Klossek, Linke, \& Nippa, 2012; Knoerich, 2010). Drawing on the LLL (linkage, leverage, and learning) framework, it was argued that business groups could help Chinese firms develop multinational advantages that yield either asset exploitation in developing countries or asset augmentation in developed countries (Yiu, 2011 ). Finally, emerging market multinational companies (EMNCs) possess certain non-market resources that originate in their home country institutional environment that could convey advantages in their own right (Cuervo-Cazurra \& Genc, 2011). Therefore, the present study suggests that the resources and mechanisms Chinese firms use to overcome liabilities of foreignness must be conceptualized more broadly than has generally been done in the literature.

For stimulating theoretical extensions, future research into the liability of foreignness could integrate RBT with other theories to consider the dynamic nature of resource deficits and social networks. By drawing on insights from RBT and network theory, scholars may specify the political, business, or social nature of networks and Chinese endeavours to overcome liabilities of foreignness. Also, because the web of interrelationship is dynamic, Chinese firms manage different liabilities in various ways at different time periods. Such competitive settings could be another fruitful area for further theoretical refinement. After all, firms that expand overseas are likely to suffer several liabilities at the same time, and the nature of resources can change as competitive settings change (Cuervo-Cazurra \& Genc, 2011 ). Therefore, future analyses could separate liabilities by their causes and disentangle the capabilities or networks needed to overcome liabilities of foreignness faced by Chinese MNCs in different contexts.

\section{RECOMMENDATIONS}

This review shows that the Chinese internationalization literature resonates with a wide range of theories contributing to management and IB studies. In particular, scholars try to connect resources and institutions through the RBT and institutional theory, and show how Chinese MNCs nurture, accumulate, and build capability in various institutional settings. Empirical evidence across the four primary areas somewhat validates the reciprocal effect of resources and institutions in the international expansion of Chinese firms. This systematic review also raises important questions about the degree of integration across theories and the extent to which a cumulative body of knowledge is emerging. It has here been observed that more than 50 percent of the studies did not specify their theoretical conceptualizations nor did they present clear theoretical models. Many studies use Chinese OFDI simply as a research setting, with scant attention to theoretical extension. In this section, five recommendations are oflered for moving research forward in terms of theoretical extension and development. 


\section{Recommendation 1: Cross-fertilization among the Four Research Streams}

One area that may directly benefit from incorporating research from another area is the research on catch-up strategies and liabilities of foreignness. At the core of the two research themes is the question of whether or how Chinese firms with limited or constrained capabilities build their firm-specific assets in reducing the costs of doing business abroad and catching up with established MNGs (Luo \& Tung, 2007; Rugman, 2010). Recent latecomer work that differentiates between the exploitation and exploration of Chinese internationalization might profit from the liability of foreignness research that distinguishes the types of resource deficit, multiplicity of disadvantages, and the dynamic nature of these relationships. Although these two areas are examined using similar theoretical approaches, they may benefit from synergy. Specifically, work on the liability of foreignness may benefit from the latecomer perspective by examining specific resources and capabilities that cross-border M\&As bring to Chinese MNCs as well as an effective mechanism to deploy them. For instance, are the resources and capabilities that contribute to catch-up strategies similar to those that might overcome the liability of foreignness? Will Chinese firms need different network capital or relational assets when they acquire different tangible or intangible assets in their international expansion?

Similarly, research on the liability of foreignness may benefit from dynamic considerations of the role of government regarding dual yet disparate institutional forces - institutional escapism and governmental promotion (Luo et al., 2010). Nlthough Chinese firms are engaged in multiple resource-seeking strategies (Kolstad \& Wiig, 2012), scholars have rarely considered such strategies in enhancing their competitive edge simultaneously. Because of this research void, we know little about how different strategies complement each other to reduce social or institutional liabilities and compensate for competitive weakness. Do these strategies work independently or as substitutes with little or no change in (dis)advantages? Do Chinese MNCs progress through a sequence of activities or do they frist look to government incentives before increasing their international engagements? How does the decision to engage in asset-driven M\&As affect the decision to reduce the liability of foreignness or to comply with government regulations or priorities? Future research can delineate the differences or similarities among these strategies to understand their tradeoff and complementarities.

With the rise of Chinese SOEs as a powerful force in global investment, the role of the Chinese state as a cross-border investor is of immediate relevance. In terms of promoting international endeavours and engaging its economies in the global landscape, the Chinese state can act as both a strategic entrepreneur, recognizing opportunities in its environment, and an institutional entrepreneur, crafting the institutions required to capitalize on these opportunities. Since Chinese SOEs sit at 
the crossroads between IB and the political economy, research can benefit from cxamining the intersection of these two ficlds spanning theorctical boundarics to enhance our understanding of the complexities associated with state-directed OFDI. Many questions can be explored. For example, how do Chinese governments at different levels foster state-to-state relationships that help SOEs access vital resources and/or overcome liabilities of foreignness? What catch-up mechanisms can promote such ventures and shield them from changes in the political climate? Chinese state ownership imposes unique demands on organizations as they strive to meet the conflicting objectives of economic performance and national mission. What key determinants drive the level of involvement of the state as the owner in strategic decisions of a globalized SOE? Does the degree of involvement change with the success or failure of the overseas efforts? How has global exposure altered the nature of the relationship between Chinese SOEs and their home and host countries?

As the progressive Chinese state has systematically explored opportunities to invest abroad, Chinese outward investment offers a unique opportunity to challenge and extend existing theories of the MNCs along interdisciplinary lines. Analyzing the internationalization of Chinese SOEs can serve as an incubator for interdisciplinary studies, including business and government, developmental economics, industrial policy, and public administration, thereby contributing to the debates on the global role of SOEs that are collectively reshaping the global impact of the state. Chinese OFDI is a multifaceted phenomenon. Crossdisciplinary inquiries would uncover the multiple layers of causal dynamics and their interrelationships (Zahra \& Newey, 2009).

\section{Recommendation 2: Integrate Predominant Theories with Other Theoretical Lenses}

Although industry-based economics is important (Yang, Lim, Sakurai, \& Seo, $2009 \mathrm{~b}), \mathrm{RBT}$ and institutional theory are the two predominant theoretical perspectives in research on Chinese OFDI. While RBT tends to be the primary theory in analyzing catch-up strategies and liabilities of foreignness, institutional theory appears to dominate the other two research streams. However, no theory is sufficient on its own, whatever the area. TCE or Dunning's eclectic paradigm has been the favoured partner of RBT in explaining the liability of foreignness (Lau, Ngo, \& Yiu, 2010) and catch-up strategies (Bonaglia et al., 2007), whereas RBT is the primary partner of institutional theory in exploring the dynamic relations between firms and institutions (Deng, 2009). Regarding the role of the Chinese state and government, researchers tend to adopt a political economy perspective to broaden the application of institutional theory (Deng, 2004; Luo et al., 2010). In identifying specific mechanisms for Chinese investors to overcome liabilities of foreignness, scholars tend to integrate network theory with RBT (Teagarden \& 
Cai, 2009). Therefore, more work devoted to Chinese outward investment should draw on the rich insights of other theoretical lenses for understanding this complicated issue.

Specifically, integrating resource dependence theory (RDT) with RBT could be highly productive given the dominant state ownership in Chinese overseas investment. RDT posits that firms depending significantly on external resources will attempt to minimize or neutralize this dependence (Pfeffer, 1993; Pfeffer \& Salancik, 1978). Because these two theories show complementary focuses on resources, integrating them may show how organizations achieve a competitive edge and reduce environmental uncertainties simultaneously by specifying resource needs internally and obtaining them externally (Hillman et al., 2009). We need a richer understanding of specific resources that different levels of Chinese government bring to a firm, as well as their motivation and ability to contribute to the firm. For example, does resource dependence influence catch-up strategies? If so, what type and to what extent? Researchers may further explore how extensively Chinese internationalization relates to government dependence and analyze the stages of a Chinese firm's international engagements in which external resources are most beneficial. Corresponding to the different resources that M\&As bring to a firm, scholars may examine how specific types of $M \& \Lambda$ s may be more or less valuable as government factors change. Furthermore, organizations may use political means to alter the external environment, actively creating their own favourable environment by trying to shape government policies.

Integration of RDT and institutional theory may prove equally enlightening because of their different levels of analysis. At its foundation, institutional theory builds on several macro perspectives (e.g., formal regulations, informal rules, or social isomorphism). As a micro-level approach, RDT contends that organizations are constrained by a network of interdependencies with institutions, and that employees rely on their team members to perform successfully (Hillman et al., 2009; Pfeffer, 1993). Therefore, the micro-macro conceptualizations of RDT and institutional theory share a focus on reciprocal relationships for managing external interdependencies and generating successful performance. Search for the theoretical synergies between institutional legitimacy and forms of resource dependency may offer new insights into Chinese OFDI and contribute to the overall body of knowledge. For instance, scholars may consider parallels between exploitation and exploration at the firm level and impetus and restraints at the institutional level that may emulate similar forces frequently studied in terms of firm actions. Also, as the two theories share some common assumptions regarding strategic options but emphasize the socially embedded context of firms, it could be fruitful to explore more nuanced relationships between internal/external resources and performance.

Another potential theoretical lens for integration involves institutional theory and stakeholder theory because of their similar emphases. Both theories recognize 
the firm's interdependence on external environments (institutions) and internal contingencics (stakcholders). Research in stakcholder theory has becn refined to explain which stakeholders take precedence in different settings (Mitchell, Agle, \& Wood, 1997), and that might be a constructive frame of reference for institutional scholars. Emerging economies, particularly China, are not homogenous (Morck, Yeung, \& Zhao, 2008). Instead, institutions are significantly different at national, provincial, and local levels. Studying regional differences within China would enhance our understanding of important nuances. Unfortunately, studies are almost cxclusively on central governmental influences; subnational institutional influences on Chinese OFDI have not been considered. By combining institutional theory's recognition of the multiplicity of institutions with insights from stakeholder theory regarding stakeholder importance, we could obtain greater insights into how national and regional institutional factors influence Chinese MNGs in their overseas engagements and differentiate which institutions take precedence if multiple governmental agencies co-exist.

The complex interplay between Chinese firms and their institutional setting requires robust approaches. Juxtaposing RBT and institutional theory with other important theories, especially with RDT, may depict this complicated interaction more realistically, and may also realize new applications of both RBT and institutional theory in the context of Chinese OFDI featuring dominant state role and ownership.

\section{Recommendation 3: Attention to the Process Dimensions via Longitudinal Studies}

The dynamic nature of Chinese outward investment requires longitudinal methods and process models. Several studies capture some of these longitudinal characteristics and implementation-related issues (see, e.g., Marinova, Child, \& Marinov, 2011 ), but we need dynamic, longitudinal models incorporating variables addressing other organizational or decision-making factors that affect the viability and intensity of Chinese OFDI. In essence, studying Chinese internationalization is seen as a way to enrich theory, particularly about how Chinese MNCs can sustain or improve their international performance when they lack globally valuable resources.

Studies on the motivations and determinants of Chinese OFDI dominate the field; those on processes of Chinese investment are significantly underrepresented (Deng, 2012). Consequently, researchers have failed to explore what occurs within and between Chinese internationalization or to address the interplay between business and political dimensions of this complex issue, particularly regarding the Chinese state as a cross-border investor. Moreover, comprehension is rather limited relating to the formation and integration of M\&As, the processes linking knowledge transfer and competitive enhancement, and the content and nature 
of corporate-subsidiary governance. Regarding these gaps, another promising research stream might develop an integrative model considering Chinese overseas investment as a process. For example, if social networks offer a special ownership advantage for Chinese MNCs (see, e.g., Yiu et al., 2007), scholars may further investigate network dimensions for overcoming the liabilities of foreignness: what does networking entail? Which process is used for selecting networks and deploying social capital? What market and non-market factors impact this process? How and when does network capital formulate and transform to special ownership advantages for Chinesc firms? How do networks deal with the dynamic context where Chinese foreign subsidiaries grow and thrive? How can Chinese political networks be incorporated into Chinese MNCs at different stages of overseas investments? Research can delve into why and how Chinese firms use and exploit political networks with the Chinese state before and after their OFDI undertakings. Do political ties recede once a Chinese firm has internationalized? Do they recede because of misconceptions in the host country, because they are no longer needed, or for other reasons? Does the Chinese firm exploit alternative political networks and how?

These issues are by no means easy to deal with and require longitudinal approaches that allow continuity to be recorded, as opposed to snapshots of a particular point in time (Zahra \& Newey, 2009). Studying Chinese MNCs can enrich and enhance existing theory by focusing on the process of how they become truly competitive multinationals. Longitudinal approaches enable a fuller and more complete understanding of the content-process framework of Chinese OFDI.

\section{Recommendation 4: Conduct Multiple Levels of Analysis}

Multilevel factors that include macro environmental forces and micro firm-level dynamics jointly drive Chinese overseas investment (Hitt, Beamish, Jackson, \& Mathieu, 2007). However, most empirical studies tend to examine it from a single level, yielding incomplete interpretations and sometimes conflicting findings. Moreover, research has been slow to determine the multilevel conditions that jointly affect Chinese firms' strategic choices and mechanisms to overcome their liabilities of foreignness socially and institutionally. Research at the organizational, industry/country-level has generally relied on official Chinese national or industry level data, neglecting micro-level (individual or group) factors. Consequently, we have limited knowledge of decision-making mechanisms associated with Chinese OFDI. This article argues for greater attention to how characteristics of Chinese managers, particularly top management teams (e.g., entrepreneurship, managerial professionalism), combine with macro-level factors in explaining different levels and stages of Chinese outward investment.

Chinese MNCs seek knowledge in advanced nations to overcome their inherent disadvantages as latecomers. Knowledge-seeking FDI could offer distinct 
advantages in terms of a multilevel analysis of reverse knowledge transfer. For cxample, rescarchers might explore the Chinese govcrnment's influence in transferring knowledge to China and sharing with other firms to improve overall technological capabilities at home. We could examine how foreign subsidiary characteristics (e.g., willingness and intra-firm ties) and relationship characteristics (e.g., internal embeddedness and socialization mechanisms) impact the reverse knowledge transfer to Chinese parent firms (Li, Zhang, \& Lyles, 2013). Relatedly, a micro-level analysis taking individuals or groups as the unit of analysis would help explain how acquired knowledge could be absorbed in cross-border knowledge management. Theoretically, multilevel research could be implemented through integration of theories at the macro level (e.g., institutional theory) and micro level (e.g., RDT). Similarly, studies should encompass within-firm factors and external influences, perhaps by drawing on the internal asset exploitation nature of the OLI paradigm and the external asset exploration character of the LLI model. Synthesizing the two may yield a rich perspective of the joint influences of internal capabilities and external resources on Chinese investor performance.

Chinese OFDI is best considered a process evolving across levels and over time, yielding discrete sequential outcomes or manifestations at each level. Moreover, structural, social, economic, and political factors at higher levels of analysis can facilitate or constrain Chinese OFDI at lower personal and psychological levels. To encourage more holistic, ecumenical research, there is a need for greater cross-level theory building and testing on Chinese OFDI for greater cross-fertilization of ideas.

\section{Recommendation 5: Consider Comparative Studies with Emerging Market MNCs}

Rescarch on the internationalization of Chincse firms can enrich and extend mainstream IB theory for bringing context explicitly and comprehensively into the research through indigenous, context-specific research $(\mathrm{Li}, \mathrm{Leung}$, Chen, \& Luo, 2012; Tsui, 2004). It is increasingly important to develop both a Chinese theory of management and a theory of Chinese management (Barney \& Zhang, 2009) particularly through comparative studies (Child, 2009).

Foreign investment from major emerging economies will expand further as they aspire to become significant regional and global players in their respective industries (Jormanainen \& Koveshnikov, 2012; UNCTAD, 2013). Despite significant political and economic differences, from the globalization view, EMNCs have much in common. Increasingly, they internationalize to exploit competitive advantage and bolster it by acquiring new capabilities for exploitation at home and abroad, creating common challenges in catching up with Western firms and turning late-mover status into competitive advantage (Mathews, 2006). 
Given China's status as the most important emerging economy, researchers might consider how Chinese internationalization resembles or differs from that in other emerging economies. For example, it might be fruitful to examine how China and other emerging economies, with their distinctive and idiosyncratic characteristics, shape and leverage the country-specific assets (CSAs) and firm-specific assets (FSAs) of their EMNCs. To what extent are CSAs strategically relevant for the internationalization of EMNCs? Can they develop the global competencies necessary for sustaining and upgrading their competitive edge? The CSA and FSA concepts have been applied to Chinese OFDI (see, e.g., Rugman \& Li, 2007), and the matrix can be extensively explored in comparative research on EMNCs. For insightful theoretical contributions, Marinova et al. (2011) focus on the interdependence of country- and firm-specific advantages and disadvantages and use a solid longitudinal perspective to argue that strategic resources are the key to the internationalization of Chinese firms.

In addition, business groups prevail in many emerging economies (Carney, Shapiro, \& Tang, 2009), and it is valuable to study how business group affiliation is important in the internationalization of various EMINCs. In terms of inter-firm networks, business groups could be a critical source of non-market competitive advantages for many EMNCs. Using an integrated view of OLI theory and LLI framework, Yiu (2011) theoretically explores why business group affiliation, compared with independently structured firms, might accelerate international expansion. Studies may compare Chinese business group topics with those in other emerging economies with diverse political histories, such as colonialism or communism, and examine whether business group ties are more important in certain phases of the internationalization of EMNCs. What ingredients are most relevant in initial, secondary, and final internationalization phases? Chinese business groups may be superficially similar to those in other emerging economies, but deeper analysis might uncover substantial differences. Furthermore, business groups depend highly on governments to secure key resources and face unique risks associated with political ties. Researchers may concentrate on RDT mechanisms and processes adversely affecting political ties, particularly in the host country.

Most research on Chinese OFDI is indigenous and context-specific; comparative research is rather limited. Moreover, the limited comparative studies focus on Chinese and Indian outward investments and are descriptive. Given the strategic linkages between China and other emerging markets, more comparative studies are needed (Marinova, Child, \& Marinov, 2012). Comparing Chinese firms with South Korean and Japanese firms at similar stages of their economic development should be considered as well. Their investment strategies have been shaped by many commonly shared institutional settings and strategic factors, which include home institutional constraints, enabling government policies, and latecomer status. These comparisons would help us better understand whether Chinese MNCs 
really lag behind and whether they are following catch-up trajectories developed by Japanese and South Korean MNCs.

\section{CONGLUSION}

As Chinese companies emerge as the greatest source of competition for wellestablished multinationals, the international expansion of Chinese MNCs becomes a new theme in management and organization research. This article provides a review of scholarly works on the international expansion of Chinese MNCs from a theoretical advancement perspective. By systematically assessing the Chinese outward investment literature from 2001 to 2012, the article shows that research on Chinese OFDI can extend and develop theorizing in the latecomer perspective, government and state influences, the dynamics of firms and institutions, and the liability of foreignness. This review indicates that research needs more integrative, process-focused, dynamic perspectives within cross-disciplinary knowledge and multilevel analysis to open new avenues of theoretical inquiry. Specifically, an integration of resource- and institution-based theories with political economy perspectives to interpret the powerful role of the Chinese government and state as a cross-border investor holds the greatest promise. Such theoretical extension and development will deepen our understanding and offer vital insight on the complex phenomenon of international expansion of Chinese MNCs.

\section{NOTE}

The author gratefully acknowledges John Child, MOR Action Editor, and two anonymous reviewers for their insightful comments and constructive suggestions on an earlier version of this manuscript. The author also wishes to thank Anne Tsui (Editor-in-Chicf) and Tina Minchella (Managing Editor) for thcir extremcly helpful editorial assistance. In addition, the author is gratcful to Professor Kimberly Temme for her careful editing of the paper for typographical and grammatical crrors cluring the revicw process, and all the tcam members of the Eastern Scholar Research Team in International Trade at Shanghai Lixin University of Commerce for their valuable input and excellent rescarch assistance. This rescarch was supported in part by the Program for Professor of Special Appointment (Eastern Scholar) at Shanghai Institutions of Higher Learning and research allowances from Maryville University of St. Louis. The usual disclaimers apply. 


\section{APPENDIX I}

Articles reviewed in the three categories of the journals

Top Business and Management Journals (No. of journals: 9; No. of articles: 39) Joumal of World Business (15): Bonaglia et al. (2007); Chen and Tan (2012); Cui and Jiang (2009a); Deng (2009); Duanmu (2012); Kang and Jiang (2012); Klossck ct al. (2012); Kolstad and Wiig (2012); Liang ct al. (2012); Liu ct al. (2011); Luo ct al. (2010); Ramasamy et al. (2012); Rui and Yip (2008); Sun ct al. (2012); Zhou (2007)

Isia Pacific Joumal of Management (7): Cardoza and Fornes (2011); Chen and Young (2010); Cui and Jiang (2010); Ge and Ding (2008); Globerman and Shapiro (2009); Quer ct al. (2012); Yang et al. (2009a)

Joumal of Intemational Business Studies (7): Buckley ct al. (2007); Cui and Jiang (2012); Lu ct al. (2010); Luo and Tung (2007); Morck ct al. (2008); Yiu ct al. (2007); Zhou ct al. (2007)

Mangement and Organization Review (4): Boisot and Mcyer (2008); Child and Rodrigues (2005); Lu ct al. (2011); Yiu (201I)

Harvard Business Review (2): Williamson and Raman (2011); Zeng and Williamson (2003)

Academy of Management Perspective (1): Luo and Rui (2009)

Entrepreneurship Theory and Practice (1): Yamakawa ct al. (2008)

Intemational Journal of Management Revieres (1): Deng (2012)

Organization Studies (1): Vaara and Zhang (2012)

Other Business and Management Journals (No. of journals: 15; No. of articles: 55) Intemational Business Review (7): Fan ct al. (2012); Gao ct al. (2013); Liu ct al. (2005); Liu ct al. (2008); Shich and Wu (2012); Wang ct al. (2012); Zhang ct al. (2011)

Thunderbird International Business Review (7): Cui ct al. (2011); Deng (2010); Malhotral ct al. (2010); Ning and Sutherland (2012); Wu ct al. (201 l); Yang ct al. (2009b); Zhang ct al. (2012)

European Management Jounal (6): De Bculc and Duanmu (2012); Di Minin ct al. (2012); Liu and Li (2002); Nolan and Zhang (2003); Rugman and Li (2007); Scthi (2009)

Multinational Business Review (5): Alon (2010); Peng ct al. (2011); Sun (2009); Voss ct al. (2010); Wei $(2010)$

Chinese Management Studies (4): Lau ct al. (2010); Sutherland (2009); Yang (2009); Zhou and Schuller (2009)

Joumal of International Management (4): Knocrich (2010); Li (2007); Tolentino (2010); Zhao ct al. (2010)

Organizational Dynamics (4): Li and Kozhikode (2011); Luo ct al. (2011a); Prange (2012);

Tcagarden and Cai (2009)

Business Horizons (3): Deng (2004); Deng (2007); He and Lyles (2008)

International Marketing Review (3): Lin (2010); Yuan and Pangarkar (2010); Zou and Ghauri (2010)

Management International Review (3): Buckley et al. (2008); Jormanainen and Koveshnikov (2012); Luo ct al. (2011b)

Asian Business and Management (3): Cui and Jiang (2009b); Rugman (2010); Taylor (2002)

Aduances in Intemational Management (2): Marinova ct al. (2011); Marinova ct al. (2012)

Global Strategic Joumal (2): Peng (2012); Luo and Wang (2012)

Asia Pacific Business Review (l): Warner ct al. (2004)

Global Business and Organizational Excellence (1): Xic and Amine (2010)

International and Area Study Journals (No. of journals: 17; No. of articles: 44)

China and World Economy (9): Armstrong (2011); Clcgg and Voss (2011); Drysdale (2011); Fung et al. (2007); Huang and Wang (2011); Hurst (2011); Pci and Wang (2001); Song (2011); Song ct al. (2011)

Industrial and Corporate Change (4): Duysters et al. (2009); Fortanier and Tulder (2009); Kumar and Chadha (2009); Niosi and Tschang (2009)

Joumal of Chinese Economic and Business Studies (4): Biggeri and Sanfilippo (2009); Gattai (2012); Liu and Buck (2009); Sutherland and Ning (2011) 
Joumal of Modem African Studies (4): Brautigam and Tang (2011); Gcbrc-Egziabher (2007);

Haglund (2008); Tull (2006)

China Quarterly (3): Hong and Sun (2006); Jiang (2009); Lee (2009)

European Geography and Economics (3): Bricnen ct al. (2010); Dixon (2010); Yeung and Liu (2008)

Pacific Affairs (3): Ning (2009); Sautman and Yan (2008); Wang (2002)

Asian Survey (2): Kim (2006); Liou (2009)

China: An Intemational Joumal (2): Wong and Chan (2003); Zhao (2011)

Pacific Review (2): Frost (2004); Gonzalez-Vicente (201 l)

World Development (2): Nolan and Zhang (2002); Stcinfeld (2004)

Canadian Public Poligy (1): Antkicwicz and Whallcy (2007)

China Economic Review (1): Bhaumik and Co (2011)

Europe-Asian Studies (1): Wu and Chen (2001)

Pacific Economic Review (1): Cheung and Qjan (2009)

Research in International Business and Finance (1): King and Wcitzel (2011)

Revizw of Intemational Political Economy (1): Su (2012)

Vote: No. of journals $=41 ;$ No. of articles $=138$.

\section{REFERENCES}

*An asterisk denotes that the study was included in the review.

Alon, I., Chang, J., Fetschcrin, M., Lattemann, C., \& McIntyrc, J. (Eds.). 2009. China rules: Globalization and political transformation. New York: Palgrave Macmillan.

*Alon, T. M. 2010. Institutional analysis and the determinants of Chinese FDI. Multinational Business Review, 18(3): 1-24.

*Antkicwicz, A., \& Whallcy, J. 2007. Recent Chinese buyout activity and the implications for wider global investment rulcs. Canadian Public Policy, 33(2): 207-226.

*Armstrong, S. 2011. Assessing the scalc and potential of Chinesc investment overscas: An econometric approach. China \& World Economy, 19(4): 22-37.

Barney, J. B., \& Zhang, S. 2009. The future of Chinese management rescarch. Management and Organization Review, 5(1): 15-28.

*Bhaumik, S., \& Co, C. Y. 2011 . China's cconomic cooperation related investment. China Economic Revieze, 22(1): 75-87.

*Biggeri, M., \& Saufilippo, M. 2009. Understanding China's move into Alrica: An empirical analysis. Journal of Chinese Economic and Business Studies, 7(1): 31-54.

*Boisot, M. H., \& Meyer, M. W. 2008. Which way through the open door? Reflections on the internationalization of Chinese firms. Management and Organization Revieze, 4(3): 349365.

*Bonaglia, F., Goldstcin, A., \& Mathews, J. A. 2007. Accelerated internationalization by cmerging markcts' multinationals. Joumal of World Business, 42(4): 369-383.

Brautigam, D. 2009. The dragon's gift: The real story of China in Africa. New York: Oxford University Press.

*Brautigam, D., \& Tang, X. 2011. African Shenzhen: China's special cconomic zones in Africa. Joumal of Modem African Studies, 49(1): 27-54.

*Brienen, M. J., Burger, M. J., \& Van Oort, F. G. 2010. The gcography of Chinese and Indian greenficld investments in Europe. Eurasian Geography and Economics, 51(2): 254-273.

Bruton, G. D., \& Lau, C. M. 2008. Asian management rescarch: Status today and future outlook. Joumal of Management Studies, 45(3): 636-659.

*Buckley, P. J., Clegg, J., Cross, A. R., Liu, X., Voss, H., \& Zheng, P. 2007. The determinants of Chincsc outward forcign direct investment. Joumal of Intemational Business Studies, 38(4): 499-518.

*Buckley, P. J., Cross, A. R., Tan, H., Liu, X., \& Voss, H. 2008. Historic and emergent trends in Chincse outward dircet investment. Management International Revieve, 48(6): 715-748.

*Cardoza, G., \& Fornes, G. 2011. The internationalisation of SMEs from China: The case of Ningxia Hui Autonomous Region. Asia Pacific Joumal of Management, 28(4): 737-759. 
Carncy, M., Shapiro, D., \& Tang, Y. 2009. Busincss group performance in China: Ownership and tcmporal considerations. Management and Organization Revieze, 5(2): 167-193.

*Chen, S., \& Tan, H. 2012. Region effects in the internationalization-performance relationship in Chinese firms. Journal of World Business, 47(1): 73-80.

${ }^{*}$ Chen, Y., \& Young, M. 2010. Cross-border mergers and acquisitions by Chinese listed companies. Asia Pacific Journal of Management, 27(3): 523-539.

*Chcung, Y. W., \& Qian, X. W. 2009. The cmpirics of China's outward direct investment. Pacific Economic Revieze, 14(3): 312-341.

Child, J. 2009. Context, comparison and methodology in Chinese management rescarch. Management and Organization Revieze, 5(1): 91-105.

*Child, J., \& Rodrigues, S. B. 2005. The internationalization of Chinese firms: A case for theoretical extension. Management and Organization Revieze, 1(3): $381-410$.

Child, J., Rodrigues, S. B., \& 'Tse, K. 2012. The dynamics of inlluence in corporate co-evolution. Joumal of Management Studies, 49(7): 1246-1273.

*Clegg, J., \& Voss, H. 2011. Inside the China-EU FDI bond. China \& World Economy, 19(4): 92-108.

Cucrvo-Cazurra, A., \& Genc, M. E. 2011. Obligating, pressing, and supporting dimensions of the cnvironment and the non-market advantages of developing-country multinational companics. Journal of Management Studies, 48(2): 441-455.

*Cui, L., \& Jiang, F. 2009a. FDI entry mode choice of Chinese firms: $\Lambda$ strategic behavior perspectivc. Joumal of World Business, 44(4): 434444.

*Cui, L., \& Jiang, F. 2009b. Ownership decisions in Chincse outward FDI: An integrated conceptual framework and rescarch agenda. Asian Business \& Management, 8(3): 301-324.

*Cui, L., \& Jiang, F. 2010. Behind ownership decision of Chinese outward FDI: Resources and institutions. Asia Pacific Journal of Management, 27(4): 751-774.

*Cui, L., \& Jiang, F. 2012. State ownership effect on firms' FDI ownership decisions under institutional pressure. Joumal of Intemational Business Studies, 43: 263-284.

*Cui, L., Jiang, F., \& Stening, B. 2011. The entry-mode decision of Chinese outward FDI. Thunderbird International Business Revieze, 53(4): 483-499.

*De Beule, F., \& Duanmu, J. 2012. Locational cleterminants of internationalization: A firm-level analysis of Chinesc and Indian acquisitions. European Management Joumal, 30(3): 264277.

*Deng, P. 2004. Outward investment by Chinese MNCs: Motivations and implications. Business Horizons, 47(3): 8-16.

*Deng, P. 2007. Investing for stratcgic resources and its rationale: The case of outward FDI from Chinesc companies. Business Horizons, 50(1): 71-81.

*Deng, P. 2009. Why do Chinese firms tend to acquire strategic assets in international expansion? Joumal of World Business, 44(1): 74-84.

* Deng, P. 2010. What determines performance of cross-border M\&As by Chinese companies? An absorptive capacity perspective. Thunderbird International Business Revieze, 52(6): $509-524$.

*Deng, P. 2012. The internationalization of Chinese firms: A critical review and future research. Intemational Joumal of Management Reviews, 14(4): 408-427.

*Di Minin, A., Zhang, J., \& Gammeltoft, P. 2012. Chinesc forcign direct investment in R\&D in Europc. European Management Journal, 30(3): 189-203.

*Dixon, M. 2010. Emcrging Chinesc rolc in shaping St. Petersburg's urban landscape. Eurasian Geography and Economics, 51(6): 803-819.

*Drysdalc, P. 2011. A new look at Chinesc FDI in Australia. China \& World Economy, 19(4): $54-73$.

*Duanmu, J.-L. 2012. Firm heterogencity and location choice of Chinese multinational enterprises (MNEs). Joumal of World Business, 47(1): 64-72.

*Duysters, G., Jacob, J., Lemmens, C., \& Yu, J. 2009. Internationalization and technological catching up of emcrging multinationals. Industrial and Corporate Change, 18(2): $325-349$.

Economist. 2008. Chinese outbound investment: Dealing with Sinophobia, July 15.

Economist. 2010. Cover story: Chima buys up the world. November 13th, p. 11, pp. 81-83.

*Fan, D., Zhu, C., \& Nyland, C. 2012. Factors affecting global integration of Chinese multinationals in Australia: A qualitative analysis. Intemational Business Revieze, 21(1): 13-26. 
*Fortanicr, F., \& Tulder, R. 2009. Internationalization trajectories - a cross-country comparison. Industrial and Corporate Change, 18(2): 223-247.

*Frost, S. 2004. Chinese outward direct investment in Southeast Asia: How big are the flows and what docs it mean for the region? The Pacific Revieze, 17(3): 323-340.

*Fung, H.-G., Liu, Q. W., \& Kao, E. H. C. 2007. China's outward direct and portfolio investments. China \& World Economy, 15(6): 53-68.

*Gao, L., Liu, X., \& Zou, H. 2013. The role of human mobility in promoting Chincse outward FDI. Intemational Business Revieze, 22(2): 437-449.

*Gattai, V. 2012. Chinese ODI in Italy: An empirical investigation at the firm-level. Journal of Chinese Economic and Business Studies, 10(1): 47-66.

*Ge, G., Ding, Z. 2008. A stratcgic analysis of surging Chinese manufacturers: The case of Galanz. Asia Pacific Joumal of Management, 25(4): 667-683.

*Gebre-Egziabher, T. 2007. Impacts of Chinese imports and coping strategies of local producers. Journal of Modem African Studies, 45: 647-679.

*Globerman, S., \& Shapiro, D. 2009. Economic and stratcgic considerations surrounding Chinese FDI in the United States. Asia Pacific Joncmal of Management, 26(1): 163-183.

*Gonzalez-Vicente, R. 2011. China's engagement in South America and Africa's extractive sectors: New perspectives for resourcc curse theorics. The Pacific Review, 24(1): 65-87.

*Haglund, D. 2008. Regulating FDI in wcak African states: A case study of Chinese copper mining in Zambia. The Joumal of Modern African Studies, 46(4): 547-575.

*Hc, W. \& Lyles, M. A. 2008. China's outward forcign direct investment. Business Horizons, $51(6): 485-491$.

Hillman, A. J., Withers, M. C., \& Collins, B. J. 2009. Resource dependence theory: A revicw. Joumal of Management, 35(6): 1404-1427.

Hitt, M. A., Bcamish, P. W., Jackson, S. E., \& Mathicu, J. E. 2007. Building theoretical and empirical bridges across Icvels. Academy of Management Joumal, 50(6): 1385-1399.

*Hong, E., \& Sun, L. 2006. Dynamics of internationalization and outward investment: Chinese corporations' stratcgies. The China Quarterly, 187: 610-634.

*Huang, Y., \& Wang, B. 2011. Chinese outward direct investment: Is there a China model? China \& World Economy, 19(4): 1-21.

*Hurst, L. 2011. Comparative analysis of the determinants of China's state-owned outward direct investment in OECD and non-OECD countries. China \& World Economy, 19(4): $74-91$.

*Jiang, W. 2009. Fuclling the dragon: China's risc and its cnergy and resources extraction in Africa. China Quarterly, 199: 585-609.

*Jormanainen, I., \& Koveshnikov, A. 2012. International activities of emerging market firms. Management Intenational Revieze, 52(5): $691-715$.

*Kang, Y., \& Jiang, F. 2012. FDI location choice of Chincse multinationals in East and Southeast Asia. Journal of World Business, 47(1): 45-53.

"Kim, J. C. 2006. The political cconomy of Chinese investment in North Korca. Asian Survey, 46(6): 898-916.

*King, G., \& Weitzel, U. 2011. The internationalization of Chinesc companies. Research in Intemational Business and Finance, 25(3): 357-372.

*Klossek, A., Linke, B. M., \& Nippa, M. 2012. Chinesc enterprises in Germany. Journal of World Business, 47(1): 35-44.

*Knocrich, J. 2010. Gaining from the global ambitions of emerging cconomy enterprises. Joumal of Intemational Management, 16(2): 177-191.

*Kolstad, I. \& Wiig, A. 2012. What detcrmincs Chinese outward FDI? Journal of World Business, 47(1): 26-34.

Krug, B., \& Hendrischkc, H. 2008. Framing China: Transformation and institutional change through co-cvolution. Management and Organization Revieze, 4(1): 81-108.

*Kumar, N., \& Chadha, A. 2009. India's outward forcign direct investments in stecl industry in a Chinese comparative perspcctive. Industrial and Corporate Change, 18(2): 249267.

*Lau, C. M., Ngo, H.-Y., \& Yiu, D. W. 2010. Internationalization and organizational resources of Chinese firms. Chinese Management Studies, 4(3): 258-272.

*Lec, C. K. 2009. Raw encounters: Chinese managers, African workers and the politics of casualization in Africa's Chincsc cnclaves. The China Quarterly, 199: 647-666. 
Lewin, A. Y., \& Volberda, H. W. 1999. Prolegomena on cocvolution: A framework for rescarch on stratcgy and ncw organizational forms. Organization Sciences, 10(5): 519-534.

Li, H., Zhang, Y. A., \& Lyles, M. 2013. Knowledge search, spillovers, and creation in emerging markets. Management and Organization Revieze, 9(3): 395-412.

* [i, J. T., \& Kozhikode, R. K. 2011. Organizational learning of emerging cconomy firms: The case of China's TCL. Organizational Dynamics, 40(3): $214-221$.

*Li, P. P. 2007. Toward an integrated theory of multinational cvolution: The evidence of Chincse multinational enterprises as latecomers. Journal of International Management, 13: 296318.

Li, P. P., Leung, K., Chen, C., \& Luo, J.-D.: 2012. Indigenous research on Chinese management: What and how. Management and Organization Revieze, 8(1): 7-24.

*Liang, X., Lu, X., \& Wang, L. 2012. Outward internationalization of privatc enterprises in China. Journal of World Business, 46(1): 134-144.

*Lin, X. 2010. State versus private MNCs from China: Initial conceptualizations. International Marketing Revieze, 27(3): 366-380.

*Liou, C.-S. 2009. Burcaucratic politics and overseas investment by Chinese state-owned oil companics: Illusory champions. Asian Survey, 49(4): 670-690.

*Liu, H., \& Li, K. 2002. Strategic implications of cmerging Chinese multinationals: The Haicr case study. European Management Joumal, 20(6): 699-706.

*Liu, X., \& Buck. 'T. 2009. The intcrnationalization strategics of Chinese firms: Lenovo and BOE. Joumal of Chinese Economic and Business Studies, 7(2): 167-181.

*Liu, X., Buck, T., \& Shu, C. 2005. Chinese cconomic development, the next stage: Outward FDI? Intemational Business Review, 14(1): 97-115.

*Liu, X., Wen, X., \& Huang, X. 2008. Entreprencurship and internationalization of indigenous Chincse private-owned firms. International Business Revieze, 17(4): 488-508.

*Liu, Y., Li, Y., \& Xue, J. 2011. Ownership, strategic orientation and internationalization in cmerging markets. Journal of World Business, 46(3): 38I-393.

${ }^{*}$ Lu, J., Liu, X., \& Wang, H. 2011 . Motives lor outward FDI of Chinese private firms. Management and Organization Revieze, 7(2): 223-248.

*Lu, Y., Zhou, L., Bruton, G., \& Li, W. 2010. Capabilitics as a mediator linking resources and the international performance of entrepreneurial firms in an emerging economy. Joumal of Intemational Business Studies, 41(3): 419-436.

*Luo, Y., \& Rui, H. 2009. An ambidexterity perspective toward multinational enterprises from cmerging cconomics. Academy of Management Perspective, 23(4): 49-70.

*Luo, Y., \& Tung, R. L. 2007. International expansion of emerging market cntcrprises: A springboard perspective. Joumal of Intemational Business Studies, 38(4): 481-498.

*Luo, Y., \& Wang, S. L. 2012. Forcign direct investment strategics by developing country multinational. Global Strategic Journal, 2(2): 244-261.

*Luo, Y., Xuc, Q., \& Han, B. 2010. How emerging market governments promote outward FDI: Expcrience from China. Joumal of World Business, 46(1): 68-79.

*Luo, Y., Cacchionc, M., Junkunc, M., \& Lu, S. C. 201 la. Entreprencurial pioncer of international venturing: The case of Huawei. Organizational Dynamics, 40(1): 67-74.

*Luo, Y., Zhao, H., Wang, Y., \& Xi, Y. $201 \mathrm{lb}$. Venturing abroad by cmerging market enterprises. Management Intemational Revieze, 51(4): 433-459.

*Malhotral, S., Zhu, P. C., \& Locander, W. 2010. Impact of host-country corruption on U.S. and Chincsc cross-border acquisitions. Thunderbird Intemational Business Revieze, 52(6): $491-507$.

*Marinova, S., Child, J., \& Marinov, M. 2011. Evolution of lirm- and country-specific advantages and disadvantages in the process of Chinese firm internationalization. Advances in International Management, 24: 235-269.

*Marinova, S., Child, J., \& Marinov, M. 2012. Institutional field for outward direct investment: A thcoretical cxtcnsion? Advances in Intemational Management, 25: 233-261.

Mathews, J. A. 2006. Dragon multinationals: Ncw players in 21st century globalization. Asia Pacific Joumal of Management, 23(1): 5-27.

Mitchell, R. K., Agle, B., \& Wood, D. 1997. 'Toward a theory of stakeholder identification and salicncc. Academy of Management Reviez, 22: 975-996.

Ministry of Commerce, China (MOC). 2012. 2011 Statistical Bulletin of China's outward foreign direct investment. Beijing, China: China Statistics Prcss. 
*Morck, R., Ycung, B., \& Zhao, M. 2008. Perspectives on China's outward forcign direct investment. Joumal of Intemational Business Studies, 39(3): 337-350.

*Ning, L. 2009. China's leadership in the world ICT industry. Pacific Affairs, 82(1): 67-91.

*Ning, L., \& Sutherland, D. 2012. Internationalization of China's private-sector MNEs. Thunderbird Intemational Business Revieze, 54(2): 169-182.

*Niosi, J., \& Tschang, F. T. 2009. The strategics of Chincse and Indian software multinationals: Implications for internationalization thcory. Industrial and Corporate Change, 18(2): 269-294.

* Nolan, P., \& Zhang, J. 2002. The challenge of globalization for large Chinese firms. World Development, 30(12): 2089-2107.

*Nolan, P., \& 7hang, J. 2003. Globalization challenge for large firms from developing countries. European Management Joumal, 21(3): 285-299.

*Pei, C. H., \& Wang, L. 2001. Chinese corporate investment in the United States. China \& World Economy, 5(1): 17-22.

*Peng, M. W. 2012. The global strategy of emerging multinationals from China. Global Strategy Journal, 2(2): $97-107$.

*Peng, M. W., Sun, S. L., \& Blevins, D. P. 2011. The social responsibility of international business scholars. Multinational Business Revieze, 19(2): 106-1 19.

Pfeffer, J. 1993. Barricrs to the advance of organization science: Paradigm development as a dependcnt variablc. Academy of Management Reviez, 18: 599-620.

Pfeffcr, J., \& Salancik, G. R. 1978. The extemal control of organizations: A resource dependence perspective. New York: Harper \& Row.

*Prange, C. 2012. Ambidextrous internationalization strategies: The case of Chinese firms entering the world market. Organizational Dynamics, 41(2): 245-253.

*Quer, D., Claver, E., \& Rienda, L. 2012. Political risk, cultural distance, and outward forcign direct investment. Asia Pacific Joumal of Management, 29(4): 1089-1104.

Ramamurti, R., \& Singh, J. V. (Eds.). 2009. Emerging multinationals in emerging markets. New York: Cambridge University Press.

*Ramasamy, B., Yeung, M., \& Laforet, S. 2012. China's outward forcign direct investment: Location choice and firm ownership. Journal of World Business, 47(1): 17-25.

*Rugman, A. 2010. Globalization, regional multinationals and Asian cconomic development. Asian Business \& Management, 9(3): 299-317.

*Rugman, A. M., \& Li, J. 2007. Will China's multinationals succced globally or regionally? European Management Joumal, 25(5): 333-343.

*Rui, H., \& Yip, G. 2008. Foreign acquisitions by Chinese firms: A strategic intent perspective. Joumal of World Business, 43(2): 213-226.

*Sautman, B., \& Yan, H. 2008. The forest for the trecs: Trade, investment and the China-in-Africa discoursc. Pacific Affairs, 81(1): 9-29.

Sauvant, K., McAllistec, G., \& Maschek, W. A. 2010. Foreign direct investment from emerging markets: The challenges ahead. Ncw York: Palgrave Macmillan.

*Sethi, D. 2009. Is international business strategy global or regional? European Management Joumal, 27(5): 356-365.

*Shich, B.-L., \&Wu, T.-C. 2012. Equity-based entry modes of the Greater Chinese Economic Arca's forcign dircct investments in Victnam. Intemational Business Revieze, 21(3): 508-517.

*Song, H. 2011. Chinese private direct investment and the overseas Chinese network in Africa. China \& World Economy, 19(4): 109-126.

*Song, L., Yang, J., \& Zhang, Y. 2011. State-owned cnterprises' outward investment and the structural reform in China. China \& World Economy, 19(4): 38-53.

*Steinfeld, E. S. 2004. China's shallow integration: Networked production and the new challenges for late industrialization. World Development, 32(11): 1971-1987.

*Su, X. 2012. Rescaling the Chincse state and regionalization in the Great Mekong Subregion. Revieze of International Political Economy, 19(3): 501-527.

*Sun, S. L. 2009. Internationalization strategy of MNEs from emerging cconomics: The casc of Huawci. Multinational Business Reviez, 17(2): 133-159.

*Sun, S. L., Peng, M., Ren, B., \& Yan, D. 2012. A comparative ormership advantage framework for cross-border M\&As. Joumal of World Business, 47(1): 4-16.

*Sutherland, D. 2009. Do China's 'national tcam' business groups undertake stratcgic-asset-sceking OFDI? Chinese Management Studies, 3(1): 11-24. 
*Sutherland, D., \& Ning, L. 2011. Exploring 'onward-journcy' ODI strategics in China's private scctor businesses. Journal of Chinese Economic and Business Studies, 9(1): 43-65.

*Taylor, R. 2002. Globalization stratcgies of Chinese companies: Current developments and future prospects. Asian Business and Management, 1(2): 209-225.

*Teagarden, M., \& Cai, D. 2009. Learning from dragons who arc learning from us. Organizational Dynamics, 38(1): 73-81.

*Tolentino, P. E. 2010. Emerging multinationals: Outward forcign direct investment from cmerging and devcloping cconomics. Journal of International Management, 16(2): 102-120.

Tsui, A. S. 2004. Contributing to global management knowledge: A casc for high quality indigenous rescarch. Asia Pacific Joumal of Management, 21(4): 491-513.

Tsui, A. S., Schoonhoven, C. B., Mcycr, M. W., Lau, G. M., \& Milkovich, G. T. 2004. Organization and management in the midst of socictal transformation. Organization Science, 15(2): $133-144$.

Tsui, A. S., Nifadkar, S. S., \& Ou, A. Y. 2007. Cross-national, cross-cultural organizational bchavior rescarch: Advances, gaps, and recommendations. Journal of Management, 33(3): 426-478.

*Tull, D. 2006. China's engagement in Africa: Scope, significance and consequences. The Joumal of Modern African Studies, 44(3): 459-479.

UNCTAD. 2013. World investment report 2013. New York and Geneva: UNCTAD.

*Vaara, E., \& Zhang, N. 2012. The intertextual production of international relations in mergers and acquisitions. Organization Studies, 33(1): 121-148.

*Voss, H., Buckley, P. \& Cross, A. 2010. The impact of home country institutional effects on the internationalization strategy of Chinese firms. Multinational Business Revieze, 18(3): $25-48$.

*Wang, C., Hong, J., Kafourosd, M., \& Boatengc, A. 2012. What drives outward FDI of Chinese firms? Intemational Business Review, 21(3): 425-438.

*Wang, M. Y. 2002. The motivations behind China's government-initiated industrial investment overscas. Pacific Affairs, 75(2): 187-206.

*Warner, M., Ng, S.-H., \& Xu, X. 2004. Late development's experience and the cvolution of transnational firms in the P. R. of China. Asia Pacific Business Review, 10(3): 324-345.

*Wci, Z. 2010. The literature on Chincse outward FDI. Multinational Business Revieze, 18(3): 73-112.

*Williamson, P. J. \& Raman, A. P. 2011. How China reset its global acquisition stratcgy. Harvard Business Reviev, 89(4): 109-114.

*Wong, J, \& Chan, S. 2003. China's outward direct investment: Expanding worldwide. China: An International Journal, 1(2): 273-301.

*Wu, F., Hoon, L. S., Zhang, Y. 2011. Dos and don'ts for Chinese companies investing in the United Statcs. Thunderbird Intemational Business Review, 53(4): 501-515.

*Wu, H.-L., \& Chen, C.-H. 200l. An assessment of outward foreign dircet investment from China's transitional cconomy. Europe-Asia Studies, 53(8): 1235-1254.

*Xic, Y., \& Aminc, L. 2010. Social networks and the internationalization of Chinese entrepreneurs. Global Business and Organizational Excellence, 29(1): 61-78.

*Yamakawa, Y., Peng, M. W., \& Decds, D. L. 2008. What drives new ventures to internationalize from cmerging to developed cconomics? Entrepreneurship Theory and Practice, 32(1): $59-82$.

*Yang, M. 2009. Isomorphic or not? Examining cross-border mergers and acquisitions by Chinesc firms, 1985-2006. Chinese Management Studies, 3(1): 43-57.

*Yang, X., Jiang, Y., Kang, R., \& Kc, Y. 2009a. A comparative analysis of the internationalization of Chinese and Japanese firms. Asia Pacific Joumal of Management, 26: 141-162.

*Yang, X., Lim, Y., Sakurai, Y., Seo, S. 2009b. Internationalization of Chinese and Korean firms. Thunderbird International Business Review, 51(1): 37-51.

*Yeung, H. W.-C., \& Liu, W. 2008. Globalizing China: The rise of Mainland firms in the global cconomy. Eurasian Geography and Economics, 49(1): 57-86.

*Yiu, D. W. 2011 . Multinational advantages of Chinese business groups: A thcoretical cxploration. Management and Organization Revieze, 7(2): 249-277.

*Yiu, D. W., Lau, C.-M., \& Bruton, G. D. 2007. International venturing by emerging economy firms. Joumal of International Business Studies, 38(4): 519-540.

*Yuan, L., \& Pangarkar, N. 2010. Incrtia versus mimicry in location choices by Chinese multinationals. Intemational Marketing Revieve, 27(3): 295-315. 
Zahecr, S. 1995. Overcoming the liability of forcignness. Academy of Management Journal, 38: $341-364$.

Zahra, S. A., \& Newcy, L. R. 2009. Maximizing the impact of organization science. Joumal of Management Studies, 46(6): 1059-1075.

*Zeng, M., \& Williamson, P. J. 2003. The hidden dragons. Harvard Business Review, 81(10): 92-99.

*Zhang, J., Zhou, C., \& Ebbers, H. 2011. Completion of Chinese overscas acquisitions: Institutional perspectives and evidencc. Intemational Business Review, 20(2): 226-238.

*Zhang, X., Ma, X., \& Wang, Y. 2012. Entrepreneurial orientation, social capital, and the internationalization of SMEs. Thunderbird Intemational Business Reviez, 54(2): 1,95-2 10.

*Zhao, H. 2011. The cxpansion of outward FDI: A comparative study of China and India. China: An lntemational Joumal, 9(1): $1-25$.

*Zhao, W., Liu, L., \& Zhao, T. 2010. The contribution of outward direct investment to productivity changes within China, 1991-2007. Joumal of Intemational Management, 16(2): 121130.

*Zhou, L. 2007. The effects of entreprencurial proclivity and forcign market knowledge on carly intcrnationalization. Journal of World Business, 42(3): 281-293.

*Zhou, L., Wu, W., \& Luo, X. 2007. Internationalization and the performance of born-global SMEs. Joumal of Intemational Business Studies, 38(4): 673-690.

*Zliou, Y., \& Schuller, M. 2009. The internationalization of Chinese companies. Chinese Management Studies, $3(1): 25-42$.

*Zou, H., \& Ghauri, P. 2010. Intcrnationalizing by lcarning: The case of Chinese high-tech newventurcs. Intemational Marketing Revieze, 27(2): 223-244. 